\title{
Dilemmatic tensions around parenthood: the ambiguous third-party role in Assisted Reproductive Technologies and Surrogacy in France and Portugal
}

\author{
Catarina Delaunay ${ }^{1}$
}

\begin{abstract}
This article analyzes couples' attitudes towards the third-party role in Assisted Reproductive Technologies with gamete donation, and problematizes parenthood and kinship. I base my analysis on 66 in-depth interviews with different ART actors (from beneficiaries to professionals) in France and Portugal, conducted as part of a research project already completed. Special focus is given to 19 interviews with heterosexual and homosexual couples who used third-party reproduction in Europe and the United States. I found a physical and moral detachment operation among heterosexual and lesbian couples vis-a-vis the donor of reproductive potential, who is depersonalized and reduced to a functionality. The objective is to preserve the intimacy of the couple and the autonomy of the parental project. This contrasts with innovative and enlarged family dynamics developed by gay couples, who integrate both female figures (surrogate and oocyte donor) in their children's family history, through bonding efforts in a logic of reciprocity (gift and counter-gift). The purpose is to reject the negative image of a woman's body being commodified while preserving the natural appearance of procreation. I conclude that a naturalist conception of kinship persists - one based on shared biogenetic substances that bind together one parent and the donor-conceived childalong with the centrality of biological processes such as pregnancy and childbirth. There are different ways of easing tensions inherent to the contractual intervention of third parties in the reproductive process. ART re-elaborates the line of demarcation between commodities and gifts and between living things and human beings, while reconfiguring family concepts.
\end{abstract}

Keywords: Assisted Reproductive Technologies; Gamete Donation; Surrogacy; Third Parties; (Homo) Parenthood; Kinship.

\section{[es] Tensiones dilemáticas en torno a la paternidad: el ambiguo papel de terceros en las Tecnologías de Reproducción Asistida y subrogación en} Francia y Portugal

Resumen. Este artículo analiza las actitudes de las parejas hacia el papel de terceros en las Tecnologías de Reproducción Asistida (ART) con la donación de gametos, y problematiza la paternidad y el parentesco. Baso mi análisis en 66 entrevistas en profundidad con diferentes actores de ART (desde beneficiarios hasta profesionales) en Francia y Portugal, realizadas como parte de un proyecto de investigación ya completado. Se presta especial atención a 19 entrevistas con parejas heterosexuales y homosexuales que utilizaron reproducción de terceros en Europa y los Estados

Universidade Nova de Lisboa (Portugal).

E-mail: catdelaunay@gmail.com 
Unidos. Encontré una operación de desapego físico y moral entre parejas heterosexuales y lesbianas frente al donante con potencial reproductivo, que se despersonaliza y se reduce a una funcionalidad. El objetivo es preservar la intimidad de la pareja y la autonomía del proyecto parental. Esto contrasta con la dinámica familiar innovadora y ampliada desarrollada por las parejas homosexuales, que integran figuras femeninas (donante sustituto y ovocito) en la historia familiar de sus hijos, a través de esfuerzos de unión en una lógica de reciprocidad (regalo y contra-regalo). El propósito es rechazar la imagen negativa de que el cuerpo de una mujer sea mercantilizado mientras se preserva la apariencia natural de la procreación. Concluyo que persiste una concepción naturalista del parentesco, una basada en sustancias biogenéticas compartidas que unen a uno de los padres y al hijo concebido por el donante, junto con la centralidad de los procesos biológicos como el embarazo y el parto. Existen diferentes formas de aliviar las tensiones inherentes a la intervención contractual de terceros en el proceso reproductivo. ART reelabora la línea de demarcación entre mercancías y regalos y entre seres vivos y seres humanos, mientras reconfigura los conceptos familiares.

Palabras clave: tecnologías de reproducción asistida; donación de gametos; subrogación; terceros; (homo)paternidad; parentesco.

Cómo citar: Delaunay, C. (2019): "Dilemmatic tensions around parenthood: the ambiguous thirdparty role in Assisted Reproductive Technologies and Surrogacy in France and Portugal", Política y Sociedad, 56(2), pp. 381-404.

Summary . 1. Introduction. 2. Methodology. 3. Between proximity and distance to the third-party donor. 4. Dual relationships to gamete donors in AI/IVF. 5. The unbearable presence of the third party in AI/IVF: the detachment operati. 6. Gay male surrogacy: mutual choice and reciprocal engagement. 7. Surrogate children's personhood: gay male couples' perspective. 8. Conclusions. 9. Bibliography.

\section{Introduction}

This paper analyses dilemmatic tensions around parenthood and kinship among couples using Assisted Reproductive Technologies (ART) with third-party gamete donation and/or surrogacy to conceive. These tensions occur between two contradictory principles: the right of a child to know her genetic or biological origins and the right of a donor to remain anonymous. Although people have long been debating over which of these should take priority, donor anonymity is currently prioritised by French law and, until very recently, the same was true in Portugal.

ART is about making babies and parents simultaneously, through a complex process where biological reproduction is intertwined with the personal, political, and technological meanings of reproduction. Nevertheless, tensions between legal, biological and social conceptions of parenthood prevail.

The paper describes couples' attitudes towards the third party involved in assisted conception in both countries. On the one hand, we witness detachment dynamics in physical and moral terms in heterosexual couples - and to a lesser extent in lesbian couples ${ }^{2}$ - regarding the third-party donor, through a differentiation between living things (gametes) and human beings (children). The heterosexual women interviewed see any potential close relationship with the third-

\footnotetext{
2 For this article, I intentionally chose to focus on heterosexual and gay male couples to the detriment of lesbian couples, because although most of the latter also opt for anonymous donors, they do not express such deep concerns about third parties as heterosexual women do. This may be due to a range of contextual differences between oocyte and sperm donations. Nevertheless, specific lesbian couples' preferences concerning biogenetic links are discussed at various points in this article where deemed relevant.
} 
party donor (oocytes and/or sperm) negatively. Furthermore, the prospect of lifting donor anonymity is perceived as disturbing. They are embarrassed about or negatively judge the possibility that the third-party donor might intrude into the intimate relationship they have with their spouse and child or with their own body. This process reaches the point of erasing the third party, which is totally eliminated from the private sphere. In this context, I introduce the concept of an operation of detachment (Delaunay, 2017) to analyze the strategies developed by these heterosexual women that allow them to keep the donor at a reassuring distance.

On the other hand - and contrary to this dual, ambivalent, even problematic relationship - the gay couples encountered embrace enlarged familial dynamics and make bonding efforts. More specifically, French gay couples build closeness with the surrogate and sometimes also maintain contact with the oocyte donor, although they do so without knowing her identity in a semi-anonymized legal framework in the case of the $\mathrm{USA}^{3}$, where the child can only contact her on reaching the age of 18. These gay couples integrate both female figures (surrogate and oocyte donor) into the personal story of their children, since they are considered as having an important role that cannot be erased.

The fundamental tension lies in the fact that heterosexual couples have to negotiate the difficulty of being infertile with having to introduce a third-party donation in their project to have a child; an ambiguous experience of both finding a solution and introducing a possible new form of disruption in their lives, in addition to a diagnosis of infertility. "Disrupted lives" (Becker, 1997) refers to a biographical rupture and discontinuity due to major emotional crises that force people to reorganize their plans and expectations, as well as to give another meaning to their lives.

Although the discussion of couples' different attitudes towards third parties is based on a contrast between heterosexual users of ART (artificial insemination with donor sperm, in vitro fertilization with egg, sperm or double donation) and same-sex users of surrogacy (gestational surrogacy), this does not mean that these differences are connected to sexual orientation; rather, they pertain to different uses of reproductive technologies.

\section{Methodology}

Building upon previous research, I will present a new theoretical and empirical approach to the topics discussed. On the one hand, I introduce new analytical concepts to reflect on and better understand the renegotiation of kinship practices and norms, a renegotiation that stems from contemporary uses of third-party reproduction. My focus here is on parents' perceptions of the role of third parties. On the other hand, the France-Portugal comparison can provide data to complement existing studies on this subject. Furthermore, empirically-grounded insights into the differences between heterosexual and gay couples' uses of third

In the case of France, where surrogacy is not allowed, the legal framework on oocyte donors depends on the destination country chosen by the French couples. 
party reproduction shed light on the (comparatively) under-researched topic of gay surrogacy.

I base my analysis on 66 semistructured in-depth interviews with different actors related to ART (beneficiaries, doctors, biologists, members of ethics committees and members of parliament), in France and Portugal. In total, I conducted 20 interviews with ART beneficiaries (ten in France and ten in Portugal) and 46 among professionals (22 in France and 24 in Portugal) ${ }^{5}$.

In this article, I focus especially on interviews with ART beneficiaries: ten interviews with women ${ }^{6}$ in heterosexual couples (five French and five Portuguese) who have chosen to resort to artificial insemination (AI) or in vitro fertilization (IVF) with third-party donors (oocyte, sperm or both) in their own countries or abroad; five interviews with lesbian couples or just one of the partners (four in Portugal and one in France) who have turned to sperm banks in Spain, Belgium or Denmark; and interviews with four French gay male couples ${ }^{7}$ - or just one of the partners - who have resorted to a process that engages both a surrogate and a separate oocyte donor in the USA.

To reach heterosexual beneficiaries, I published a message on the websites of two infertility associations (the Portuguese Association of Fertility and the French Association MAIA) explaining the nature and scope of the research project and asking for personal testimonies. Same-sex couples were found through LGBT associations (which campaign for lesbian, gay, bisexual, trans and intersex rights), where I left a message describing the aim of the study and asking about couples' experience, or through a network of informal contacts.

Empirical data was collected between January 2013 and April 2016 as part of my post-doctoral project, which analyzed controversies and tensions, visible or invisible, around ART with gamete donation in France and Portugal. Although it does not systematically compare France and Portugal, this article emphasizes similar existential problems which arise in different national contexts. I seek to stress the complexity of third-party reproduction by drawing attention to the internal paradoxes or tensions specific to this biomedical device, but also to bring to light beneficiaries' personal limits in both France and Portugal. For this paper, I

$4 \quad$ It should however be clarified that not only gay men resort to surrogacy. Thus there is a whole analysis about heterosexual and lesbian couples, as well as single people, who decide to have children through surrogacy.

5 As my research was qualitative, interviewees were selected not through a statistical criterion, but because they were accessible and available to be interviewed (convenience sampling). The criterion of being voluntary for the study was mainly valid in the specific case of the beneficiaries (homo and heterosexual), since ethical reasons prevented all the elements of these groups from being identified. However, I did attempt to interview a considerable number of people in each of these groups, and also to meet the criterion of diversity (namely by ensuring that the health professionals I talked to from the public and private sectors worked in geographically distinct institutions and that the deputies were from different political parties). Being a non-probabilistic sample, we cannot generalize from the results I obtained with statistical precision. Nor it was considered relevant to present socio-demographic and economic characteristics of the interviewees.

6 None of the male partners was available to be questioned, even if they were present at the time of the interview and the interviewer asked them directly to give their testimony too. It is therefore women who speak on this subject, either when participating in infertility associations' online discussion forums (where men are almost entirely absent), or when responding to interview requests (for academic studies or media reports). This may be due to the fact that ART technologies always involve the medicalization of women's bodies, regardless of the origin of the infertility problem (female or male), and also because women are under pressure, hoping for a successful pregnancy.

7 I only interviewed gay male couples in France. The difficulty of finding Portuguese users of surrogacy may be due either to factors external to the study itself — such as different social or legal attitudes to gay surrogacyor variations in my approach to the field. 
intentionally focused on the most challenging situations faced by beneficiaries concerning the third-party donor, in order to highlight certain institutional flaws and disorders in the procedure governing the use of third-party genetic contribution in ART.

Beyond ART being subject to quite similar legal frameworks in both countries, each has its own institutional particularities. Both France (through Law No. 2011814 of $7^{\text {th }}$ July 2011 on bioethics and Art. L. 2141-2 of the Code of Public Health) and Portugal (under Law No. 32/2006 of $26^{\text {th }}$ July 2006) ${ }^{8}$ adopt a therapeutic approach to ART. A couple must prove they have health problems (either infertility or risk of disease transmission) in order to acquire the ART beneficiary status. To these medical conditions are added certain social conditions: the interest of the child to be born to a stable and united parental couple, and the choices that society makes by establishing certain forms of parenthood. Surrogacy was forbidden in both countries. It should be noted that in France, gamete donation is completely free because it is historically established as analogous to the donation of other human body products (blood, bone marrow). Conversely, in Portugal, donors receive a fixed amount of monetary compensation, set by the national ethics committee, as reimbursement for expenses and inconveniences (time, discomfort and risk) resulting from the gamete retrieval and transfer procedure.

\section{Between proximity and distance to the third-party donor}

The Public Gametes Bank in Portugal and the $\operatorname{CECOS}^{9}$ in France function according to the similarity rule, i.e. the matching of donors and recipients according to ethnic or morphological criteria (color of skin, eyes and hair) and blood type. The purpose and justification for this pairing is to naturalize ${ }^{10}$ the reproduction process (as a simulacrum of natural human conception), to promote identification between parents and their children (to include them in the family genealogy and to protect them all from destabilizing questions), and to maintain the confidentiality of the progenitor's identity guaranteed by donor anonymity.

Physical similarities - even if they do not stem from genetics - are associated with the biological (nature) and function as clear "proof" of the coincidence between parenthood and procreation (Fortier, 2009). Since it is related to physical

\footnotetext{
In Portugal, the 2006 ART law was changed in mid-2016 (through Law No. 17/2016, of $20^{\text {th }}$ June 2016), opening up ART to all women - regardless of their marital status or sexual orientation - and thus covering both single people and lesbian couples. At the same time, heterosexual couples were given access to surrogacy in a restricted range of medical situations that prevent pregnancy - such as the congenital or acquired absence of a functioning uterus - although they were prohibited from making any payment for surrogacy services except as reimbursement for medical costs directly related to the pregnancy (Law No. 25/2016, of $22^{\text {th }}$ August 2016). In April 2018, the Constitutional Court - asked to give its opinion on recent legislative changes regarding surrogacy - ruled against anonymous gamete donation on the basis of children's fundamental right to personal identity and personality development (Constitutional Court ruling No. 225/2018). But my interviews correspond to an earlier legislative context.

9 CECOS - Centres d'Etudes et de Conservation des CEufs et du Sperme.

10 I use the term "naturalize" in an ontological sense (and not epistemologically or anthropologically): that of eliminating or seeking to eliminate from our ontology all objects and properties that come under morality or sociology (the gamete donation and the third-party donor), in favour of others that refer to observable objects and physical properties. In this case, the latter are physiognomic similarities between prospective parents and donor-conceived children, but also biological processes such as a woman's pregnancy and childbirth.
} 
appearance (visibility), it introduces a continuity of lineage (resemblance) where there is a discontinuity of biology (lack of genetic links).

In both France and Portugal, the law prohibits the selection of potential donors of biogenic substances in some cases; these interdictions transcribe implicit social norms, excluding third-party donors whose proximity is too marked, or whose distance is too pronounced. As can be seen in the following extracts, family members (sisters, for example) and close relations of mutual acquaintance (someone known such as a neighbor) as well as donors with ethnic differences (non-matching in phenotypic and genotypic terms) are prohibited. The underlying reason is that these situations could lead to discomfort, conflict or disruption within the family or between the family and others, including donors.

I prefer anonymity. It's not for legal reasons, it's a matter of [avoiding] confusion later. My sister told me, "Oh, I want to donate! If I donate everything will be fine". Surely not! Why make room for confusion? There is no reason to risk a family drama at some point. (Isa, ${ }^{11}$ Portuguese, 39 y/o, married, 3 y/o daughter)

I just wanted him to be Caucasian. If he was black or of another race, it would be a little odd, wouldn't it? With this idea of not telling anyone, it wouldn't have gone well. (...) If he was a Portuguese donor, he could even be my neighbor, I don't know. And sometimes it can happen, perhaps, a surprise, the child could look like someone I know. (...) I don't know who the donor is and it doesn't matter! But the fact that he is Spanish has given me some assurance and, in principle, he's not very close (Bia, Portuguese $34 \mathrm{y} / \mathrm{o}$, married, $4 \mathrm{y} / \mathrm{o}$ twins).

I have Polish origins, so I thought it was nice to use a donor who was from Eastern Europe [Czech Republic]. (...) Of course, it was important for us that she was anonymous. (...) We didn't want to know who she is. She is a good fairy who helps us but to have a face, a name, to know more, it's not useful for us (Lily, French, 38 $\mathrm{y} / \mathrm{o}$, civil union, no children).

I think it has to be anonymous (...) I prefer not to know who made the donation. For various reasons. It would probably create bonds, because I would like to know, and vice versa, and it might be a bit odd (Dani, Portuguese, $39 \mathrm{y} / \mathrm{o}$, married, no children).

If I knew who he was, it would make me feel uncomfortable, because I would say to myself "it's him". I would feel uneasy. Here, at least, I tell myself that the fact that he is anonymous, it can be anyone. (...) But if I know who he is, there will be this worry. While if he is anonymous, I don't have that worry. The donor doesn't know that it's me and I don't know it's him (Chloe, French, 38 y/o, married, 4 y/o and $1 \mathrm{y} / \mathrm{o}$ twins).

In France, the first bioethics laws of 1994 established the irreversible anonymity of gamete donors according to the "model of a carnal pseudo-procreation" based on "the misleading use of the presumption of paternity" (Théry \& Leroyer, 2014: 17

11 All names cited in the excerpts from our interviews have been changed in order to protect the interviewees' privacy and anonymity. 
and 54) - the sterile husband is considered the child's father- and the denial of the gift.

In ART processes, the conflict between the right of the child to know her origins and the right of the gamete donor to remain anonymous leads us to question social representations and values (related to nature, technique and kinship), which generate tensions between contradictory principles (Cadoret \& Wilgaux, 2007; Delaunay, 2015).

The debate between supporters and opponents of maintaining gamete donors' anonymity corresponds to two different conceptions of parenthood: it opposes the social and the child's right to know her origins, on one side, to the natural and the need to preserve a traditional family model, on the other (Mathieu, 2013). Some authors thus propose a new parental model that they call "pluriparentality" (Théry, 2010), which introduces other parents into the process of conceiving a new life.

However, as I will now demonstrate, heterosexual couples find that certain arrangements ease tensions and anxiety associated with the uncomfortable and disturbing presence or proximity of a third-party.

\section{Dual relationships to gamete donors in AI/IVF}

The heterosexual women interviewed in both countries had similar biographical and care pathways regarding family-formation and reproductive issues. It is marked by a succession of hardships, failures and new starts - generating uncertainty - and by the difficult experience of sterility (the identity crisis associated with the diagnosis of infertility).

When the couple decided to have children, the woman stopped taking the contraceptive pill; then, due to the non-occurrence of a pregnancy in the following year, the couple searched for medical help. In the case of men diagnosed with azoospermia, the couple was soon offered sperm donation when intracytoplasmic sperm injection (ICSI) didn't work. On the contrary, women with endometriosis or premature ovarian failure were subjected, over a decade, to several attempted ART treatments, namely artificial insemination (AI) and in vitro fertilization (IVF), before opting for oocyte donation or double gamete donation (oocytes and sperm).

The women interviewed claim a right to the use of third-party reproduction not only in the name of their personal desire to have a child, but in the name of a general conception of what is right for all couples in that situation, that is to say, the right to be parents even for those with infertility problems.

The interviewees use different types of argument not only to criticize possible interferences of the third-party donor, male or female - I have not found a gendered logic - but also to justify their own options. The justification for choosing a third-party donor is based on an instrumental view of action that privileges the principle of utility, evaluating behaviors according to their effects. Third-party gametes are resources valued for their effectiveness and functionality, for their reproductive potential, i.e. their capacity to help to generate a child, under medical conditions, within an infertile couple.

The interviewees assess the legitimate options for having a child, identifying third-party reproduction as the goal to pursue; likewise, they value pregnancy as 
the desired state to achieve (or already achieved). The interviewees thus emphasize the importance of selecting donors who have "good gametes", that is to say, who can provide higher fertility success rates, quality of embryos and development of the fetus (efficacy). This abstract evaluation of third-party donors and gametes by infertile couples appropriates and retranslates the medical discourse on ART, which conveys an anonymized and biologizing conception of gamete donation (Delaunay \& Martins, 2015).

For the Portuguese women interviewed, suppressing the existence of the female donor as a person and taking away all her rights over the as-yet-unborn or already existing child led to criticism of her economic interest. As the following extract highlights, the motivation attributed to the donor is the financial benefit of oocyte donation (monetary compensation) and not altruism, which is contrasted with close emotional bonds (the love of the mother who gives birth to her child). There is moral judgment of the donor, who must be held accountable for her actions within a contractual agreement under which she received money.

It's financial. This is not altruism. (...) Because the donor at that time had no feelings, on the contrary, I think it is a very exhausting process. It has nothing to do with love. (...) The donor made a donation, signed a contract, received money for a troublesome medical procedure and all that. She accepted, it's over. And I think she must be aware of that. And I hope that, legally, it becomes very clear. (...) Since she sold because she was paid. And she had no personal experience with this child. So I think that in this case she has no rights, either personal nor legal" (Isa, Portuguese, $39 \mathrm{y} / \mathrm{o}$, married, $3 \mathrm{y} / \mathrm{o}$ daughter).

ART with third-party donors cannot be considered as a treatment to cure a sterile person since it is "a new way to conceive a child" (Théry, 2010: 17). It is based on the cooperation between a pair of institutional parents (only one of whom conceives) and a gamete donor who gives his/her procreative potential to enable them to carry out a parental project. Furthermore, although very diverse arrangements exist or have existed in the societies traditionally studied by anthropologists (Lévi-Strauss, 2013), this arrangement is a novelty in our contemporary society, especially because specific technologies are used.

Donors can be regarded both in a positive light, allowing conception and childbirth, and as a threat, competing with intended parents; hence the prevalence of a strictly material role for donors, i.e. gamete donation needed for reproductive purposes (Martial, 2012). The "depersonalization of gametes" ensures that the child is not born from a particular person, but from "interchangeable reproduction material" (Théry, 2010: 14).

It was a detail, a way to overcome this situation and achieve this end. It was the only way we, as a couple, found, with the medical teams, to get to have this child. There is an important role for the donor, but this child's birth depends on us (Dani, Portuguese, $39 \mathrm{y} / \mathrm{o}$, married, no children).

Heterosexual couples using ART present an instrumental relationship with the donor. The donor is regarded as a mere technical object for medical purposes, a 
means to a goal: the donor is a gamete provider; whose genetic material will be retrieved for implantation elsewhere. The child's desire to know her genetic origins (the gamete donor) is perceived as mere curiosity by both the couples and the doctors interviewed, thus reducing its importance and scope.

Even when donation is perceived as an act of generosity (as a gift in Mauss' sense of pure donation) by the women surveyed, they deny the donor all rights over the child. The gametes are reduced to cells, presented only as co-adjuvants in the process (utilitarian value). French interviewees go so far as to compare gametes with other body parts, such as blood or bone marrow, thus adopting the official discourse on donation (especially evident in the laws of bioethics).

They gave gametes. It's not their child. It's like me, when I give my blood or when I give bone marrow. (...) They have no rights in the life of my children. (...) A child is a fetus, but these are cells (Chloe, French, 38 y/o, married, 4 y/o and 1 y/o twins).

It's not a problem for me to resort to egg donation because in fact the child will grow in me, it is me who will carry him/her, feel him/her grow, move, etc. When the embryo is put in my body, it's just cells, it's not a human being yet. (...) In any case, this child will be ours whatever happens because we want her so much (Lily, French, 38 y/o, civil union, no children).

There is a very resolute operation here that tries to transform closeness into distance because donors' proximity is considered uncomfortable. The third-party donor is completely reduced to an instrument in the couples' parental project: these women try to withdraw the donor's individuality and ability to become someone close, thus reducing him/her to a functionality. After all, the principal focus is transforming what, through the technical/medical act of insemination, grows into a life form. The couples' instrumentalisation of the donor is supported by the discourse of professionals who surround infertile couples; they themselves reduce life to its functional aspects, as evidenced by the vocabulary used in the medical discourse ${ }^{12}$ on ART with a third-party donor (Delaunay \& Martins, 2015).

\section{The unbearable presence of the third party in AI/IVF: the detachment operation}

The donor's construction as a living entity (supplier of genetic material to an infertile couple) and not as a particular person (anonymous and depersonalized donation) is emancipatory and allows the couple to restrict intimate feelings to the traditional nuclear family unit. I call this a "detachment operation" from the thirdparty donor (Delaunay, 2017). Analyzing the progressive evolution of detachment thus makes it possible to show how the initial embarrassment vis-à-vis the third party becomes a problem that affects both people and institutions more seriously.

12 The doctors we met questioned whether the child has a fundamental right to search for her genetic origins; likewise, they question the idea that knowing one's genetic origins is important for the child's personal development. For them, genes and reproductive cells are simply a medium for biological information. Genetic knowledge is only clinically and scientifically relevant when it aims at preventing the transmission of hereditary genetic disorders (screening for disease in donors or the use of preimplantation genetic diagnosis). 
In this attempt by the recipient couple to free themselves from the third-party donor, there is a kind of detachment in a physical sense (putting a distance between them and the donor by ignoring gametes' origin) but also a sort of "decommitment" or deprivation, in a moral and especially legal sense (the third-person is deprived of parental rights or responsibilities).

This detachment operation applies not only to others (the third-party donor), but also to oneself and one's body, both objectively and subjectively. The desire to become a parent leads these women to agree to renounce contributing with their genetic material (or that of their spouse) to conceive the child.

It seems important to discuss how materiality (expressed in flesh, blood and food metaphors) and information (genes) are used by couples who seek ART with third-party donors, helping them to articulate different ways of defining and reconfiguring social and biological relatedness; for them, kin structure is remediated through the mechanism of chance and the use of technology (Harrington et al., 2008).

In the case of oocyte donation - in contrast to surrogacy - the focus is not on the genetic but rather the biological and social components of parenthood. For future parents, what matters is not genes - as the excerpts below show- but bodily experiences of pregnancy and childbirth by the receiving woman, as well as the child's care and education by both parents. Interviewees' idea of parenthood is thus reconfigured, as are their ideas about corporality, since in both cases - genetic and gestational motherhood- biogenetic ties are equally highly valued.

From the moment it was possible for me to get pregnant, I renounced my genetic material. (...) For me, it's just a detail to achieve a pregnancy. So, it doesn't bother me emotionally, nor even does being the recipient of another woman's eggs (Dani, Portuguese, 39 y/o, married, no children).

It wasn't difficult at all for me to accept egg donation. I said to myself, "Well, I don't have oocytes, so if I use a donor who is younger, has no health problems, etc., that will give... We have enough oocytes to have embryos and, anyway, it's me who will receive and carry the developing embryos throughout the pregnancy, so there is no problem" (Lily, French, 38 y/o, civil union, no children).

Insofar as the donor is deprived of an existence as an individual (depersonalization) and sperm is conceived as interchangeable material (within a desexualized and medicalized donation), the anonymity rule applied to gamete donors enables the maintenance of a biologizing model of the traditional family (parenthood within a heterosexual couple) and the illusion that the social parents are the biological parents (primacy of social kinship over biological kinship); it also avoids the spectre of adultery or incest (Mathieu, 2013). However, while medical teams' arguments insist on social fatherhood (the father is the one who develops the parental project and raises the children), there is a biologisation of motherhood (the woman is a mother because she is pregnant even if she is not a progenitor) (ibidem).

Likewise, lesbian couples encountered, in both France and Portugal, have chosen anonymous sperm donors (except for one couple who opted for a semianonymous donor). Ideally, their homoparental project involves both women 
getting pregnant, one at a time, from the same male donor. This expresses both concerns about the statutory difference between biological motherhood and social motherhood, and the desire to create genetic links between their children (for them to be half-siblings). Moreover, clinics in Spain match the physical characteristics of the sperm donor with those of the non-birth mother in order to create the semblance of a genetically related two-parent family.

In the case of France and Portugal, the use of ART can be analysed as "the expression of a preference for the 'biological' component of parenthood" (Fine \& Martial, 2010: 129). The attempt to perpetuate genes, the desire to have a child conceived with the gametes of at least one of the partners (Fortier, 2009), along with women's will to experience pregnancy and childbirth, demonstrate how ART contributes to the "biologisation" of parenthood, while being organized around this already-existing understanding of kinship. Having a child genetically linked to one of the partners gives the couple a sense of genetic continuity through generations; the "as if" family thus created is placed at the heart of a history that unfolds both backwards and forwards in time (Shanley, 2002). ${ }^{13}$

Although motherhood seems quite indivisible in both widespread social representations and legal definitions, ART has enabled an unprecedented division within reproduction (Delaisi de Parseval, 2008; Courduriès, 2016). Depending on the case, motherhood may assume three different meanings or dimensions: the woman who contributes with her genetic material even if she has no physiological possibility of getting pregnant (progenitor or genetic mother); the woman who is pregnant for nine months and who gives birth (gestational mother); or the woman who planned and developed a parental project and who will raise the child she desired, even though she is unable to conceive her biologically (intended mother or social mother).

In the excerpts below, the heterosexual women interviewed discuss the primacy of affective and social parenthood (emotional bonds and child-rearing), which is superimposed on genetic links. Bodily and biological dimensions are important, but are not sufficient to define a human being. They are concerned with the question of individuation, the fabrication in utero of a unique person, who will further develop special affective attachments.

There was the question of biology and DNA. All this is very complicated, but I think it was also a journey. (...) I can tell you this internalization process wasn't very easy, but I quickly came to the conclusion that biology is worth what it is worth and maybe here it has little value (...) because we can have good genes, but it's not genes that make people. It's people who make people. Of course, I would like - and I think that my husband would have liked it too- to have a son or a daughter who had my characteristics (...), but we can list a lot of people who have biological children who do not look like their parents. So what does it matter? What matters is the love and education you give to a child. And maybe biology is not as crucial as we thought it could be. For me, I got used to the idea (Tita, Portuguese, $36 \mathrm{y} / \mathrm{o}$, married, no children).

13 However, this may not be a general characteristic, but rather specific to the French and Portuguese situations and to the countries studied in the research. For example, Melhuus (2012) found this not to be so in Norway, where people who could have one partner as the genetic parent, seem to tend to prefer adoption in order to avoid any asymmetry in the parents' relationships with the child. 
I understand the curiosity to know of those who are the result of a gamete donation. However, it's a curiosity, my eyes or mouth are similar, but it shouldn't go further. It's an often repeated motto, but the father and the mother are the ones who raise the child. (...) Genetics is unquestionable and inseparable from the individual because it's written into the genetic code. Nevertheless, it's not genetics that defines us. My children are twins and completely different from each other. Much of what they are, it's obviously inscribed in their genes, but what they are becoming bears my trace and that of my husband. Everything else comes from the experience, the experience of each person (Bia, Portuguese, 34 y/o, married, 4 y/o twins).

The distinctions made here have to do with the "innate/acquired" and the "nature/culture" (or "nature/nurture") divides. There is a debate over the relative importance of heredity (nature) and environment (culture) in a child's development, i.e. a question of whether the formation and development of a person and her behavior are determined by genetic heritage or by education.

However, the women interviewed share the idea that there is no direct causality between genetics and bodily resemblance (physiognomic or gestural) or psychic similarities (attitudes and behaviors) between parents and their offspring. They highlight the essentially acquired character of certain similarities (facial expressions, ways of walking and talking, etc.) through mimesis and identification.

They also stress the socially constructed character of parenthood, both at sociolegal and emotional levels. For them, the person (the donor-conceived child) is socially constituted within a nuclear family (prospective parents). The focus is on ontogenesis, the development of the individual from conception to adulthood. This is the process through which a "living thing" (the gamete) becomes a "human being" (a person-to-be), in the philosophical sense of "coming into being."

Ambiguity and ambivalence characterize this intermediate or transitional stage between an indeterminate set of cells (third-party donor gametes seen as body parts that medicine helps to combine with one partner's genetic material) and the future child as a person "in the process of becoming". This developing person is enrolled into a parental project, and is therefore considered a human being. The concept of "liminality" (Turner, 1969) and the classic example of the boy-man in rites of passage, who shares two contradictory roles, ${ }^{14}$ can be employed here. The liminal space of indeterminacy and uncertainty between two states in the ART process, where it is difficult to set limits, creates anxieties. But these anxieties are somewhat reduced among women during pregnancy and childbirth, because of the strong biological links they establish successively with the embryo, the fetus and the already-born child.

ART "makes parents" as well as children: it redefines parenting and the ways it is embodied, disembodied and re-embodied. ART inextricably links different institutional contexts, from ethics committees to ART centers, including legislative bodies, and entangles heavy normative processes (Thompson, 2005). Through an

14 When Victor Turner studied the rituals of the Ndembu people in Zambia, he identified three phases of rites of passage, according to Van Gennep's theory: separation, liminality, and incorporation. In the liminal and intermediate stage, individuals are no longer boys, but they are not yet men either; it is the ambiguity and the paradox of the in-between. During this transitional stage, of threshold, they develop intense relational links between them, which the author describes as communitas, an absolute interhuman relation beyond any form of structure. 
"ontological choreography" (Thompson, 2005), composed of coordinated efforts from different actors involved (couples, doctors, legislators, etc.) and the interdependent dynamics of biological reproduction at the technological, scientific, personal, legal, political and financial levels, ART helps to either (re)interpret or normalize and naturalize kinship as well as gender roles (even if the parents provide neither gametes nor uterus), thereby establishing new relations between science, technology and society.

\section{Gay male surrogacy: mutual choice and reciprocal engagement}

Within homoparental projects, the third-party donor (whether anonymous, semianonymous or known) is not likely to be totally erased, nor gamete donation to be concealed (Théry, 2010). Where access to ART is opened up to same-sex couples, public controversies about donor anonymity, access to origins and attitudes towards third parties should gain new momentum. Indeed, it is impossible to keep secrets about conception or to preserve the invisible existence of the donor (Mehl, 2008), and this changes the pseudo-procreative model that prevails in the ART law in France and, until recently, also in Portugal.

In gay male couples' ART projects, the third-party role is, conversely, of great relevance and wrapped in new cultural meanings. Nevertheless, it also raises major socio-political problems in the public sphere between what is allowed and what is forbidden in ethical terms. The parental projects of the gay couples interviewed did not start with surrogacy. Due to the ethical and financial stakes involved in surrogacy (couples were reluctant to choose what at the time was a controversial and still unknown practice), couples ruled out this possibility at the beginning. After attending discussion groups at the French APGL (Association of Gay and Lesbian Parents and Future Parents) and ADFH (Association of Homoparental Families) and meeting others involved in the same process, the gay couples considered other options such as adoption and co-parenting.

However, gay couples faced difficulties adopting abroad. Although one of the partners applied, as a single person, to adopt in several foreign countries, there are long waiting lists, a lot of uncertainty and no response in most cases. Moreover, these couples' desire to carry out a project of their own ("a real family of our own", "our child", "to welcome a child into a loving family unit") and not with other people (that is to say, with a lesbian couple or a single woman) have led them to reject co-parenting due to concerns about the child's stability. According to the interviewees, co-parenting would require prior time to build a relationship of mutual trust and friendship between the two couples. It could be a source of uncertainty and future problems concerning kinship ties with the child, but could also result in a lack of control over time, jeopardising the stability of the arrangement. Sharing the child's life and education with a female couple would mean a loss of a considerable part of the parenting experience. Other recent studies report the same findings (Gross, 2018).

Following several years of unsuccessful attempts to adopt, and especially after overcoming their previous reluctance, the four couples interviewed decided to resort to a surrogate in the United States. According to them, and compared with 
most countries providing surrogacy, the process in the U.S. is more ethical and legally regulated (offering the possibility of returning with their child to France with a passport and a proof of paternity).

Unlike in other studies which have found that both men share or alternate sperm provision for the child's conception (Dempsey, 2013), my interviewees decided that just one partner would be the sperm donor and therefore the biological father. The choice has to do with different criteria: personal desire (one of the gay men is more willing and ready for fatherhood); family circumstances (one partner is an only child and this is the only way to give his parents grandchildren); economic constraints (due to the high costs of surrogacy in the United States often just one attempt per couple is allowed). Nevertheless, parenthood is shared between the biological father and the social one. Biogenetic relatedness and other forms of relatedness (such as those based on devotion, reproductive desire, individual will and determination) complement each other to make kinship real and to strengthen gay men's affinity with their children (Nebeling Petersen, 2016).

The process of arranging transnational commercial surrogacy involved an agency (for choosing the surrogate), a clinic (for selecting the oocyte donor) and a lawyer to represent the couple on legal issues (the contract with the surrogate, legal documentation to allow the child to leave the United States, etc.). To begin with the agency offers a woman available for surrogacy who has matched with the couple based on criteria they have previously determined. The couple meets with the candidate and gets to know her and in most cases also her husband. ${ }^{15}$ One of the respondents draws a parallel between these agencies' selection of the surrogate and the modus operandi of a marriage agency. Another even compares the first meeting to a "romantic date", using expressions like "love at first sight." The surrogate's selection is either described as her own choice ("there was a surrogate who chose us") or as a reciprocal selection ("it is a mutual choice, it's a co-decision").

When I was shown the profile, I did not see myself saying, "Oh yes, it's good, but have you a second choice if this one does not work?" I think it's already so generous that a person has agreed to meet us. (...) For me, if a person agrees to do that, it's already huge. (...) We went to the agency and we met and it was a little weird. I had the impression that it was a romantic date. I was rather relaxed at the idea of meeting her because I had a good impression in advance and it was confirmed when she came later and we met properly. (...) The husband was there too all the time. And we stayed for two and a half hours with her, to get to know each other. We talked about everything. We talked about this project, we talked about what she did in life. (...) It went very well and I think we were very moved, all four of us, during this interview and we had a sort of "love at first sight". Afterwards she told us that she had immediately felt that we were the couple that she was looking for, because she felt at ease with us, and my companion and myself immediately felt comfortable too (Lucas, French, 35 y/o, partnership, no children).

For certain groups, surrogacy raises the question of lack of respect for the principles of the inalienability of the human body and the non-commodification of

Surrogates proposed by these agencies in the USA are always married, heterosexual and already have children of their own. 
living beings or human life. Although the surrogacy arrangement began as a commercial exchange for the prospective parents, surrogates shifted their understanding of it so it became seen as a gift relationship: "the payment doesn't eclipse the gift" (Teman, 2010: 211).

It is the surrogate herself who helps dissipate possible concerns and uncertainties through her speech and by revealing her motivations. The idea of the woman who carries a child for another couple only because of monetary incentives is deconstructed. The financial issue associated with surrogacy is recognized (a desire to improve living standards) but it is not construed as these women's primary motive. Besides personal fulfilment through being pregnant, they are motivated both by the altruistic desire to help others and by their direct experiences of other people's suffering. This rhetoric helps to transform the surrogacy project into pure gifting.

French political conservatives see surrogacy only as a way of commoditizing and belittling women. (...) when we met our accomplice - I like to call her that - I still had that question in mind: Why is she doing this? And why should I benefit from the fact that she is a woman to have a child of my own? I used the term benefit. I won't use it anymore. She explained to us that her husband, who confirmed all this, was an adopted child and when he was growing up, his parents always made him understand how painful it was for them not to have children and the possibility of adopting him had been a blessing for them. So she completely understands the desire of a sterile couple who cannot have children together - which two homosexuals necessarily are - to have a child. Then she wanted to help one of her friends who could not have children. So she was thinking of doing what she is doing with us today for her friend, but her friend finally managed to get pregnant. And so she thought, why not give that chance to someone else too? When we spoke with her, I felt a lot of sincerity in all that. She kept talking about the donation she gave us, about gifts (Lucas, French, 35 y/o, partnership, no children).

We met Patricia, the surrogate mother, and in fact it was Patricia who completely uninhibited us, who blew the lock on what a surrogate mother was and all that it meant, because she was the antithesis of the image one might have of a surrogate mother. (...) I think Patricia and her husband Tom, they contributed a lot to changing the image. (...) her motivations, there are two main ones: (...) her happiness at being pregnant, without necessarily having the project of having other children of her own, and the second thing, which was more political, she had been raised by a gay uncle who had died of AIDS and (...) she wanted to carry a child for a male couple. I think her surrogacy project was [motivated by] the combination of several things (Simon, French, 36 y/o, married to Jean, 2 y/o twins).

The relationship between prospective parents and the surrogate is nevertheless hybrid: it is not only contractual and monetized, but also based on gift and countergift; the continued relationship seems the best way to express mutual friendship and appreciation (Berend, 2014; Teman, 2010).

Homosexual couples build a strong connection with the surrogate, based on generosity and gifting (a "blessing" or a "gift" even if she was paid for her gestational services) as well as friendship and complicity ("our friend", "our 
accomplice"). In homoparental projects, as opposed to heterosexual ones, a third party - the surrogate mother- actively intervenes. The woman who hosts the embryo plays an active role because the arrangement requires the reciprocal openness of each party (the gay couple and the surrogate) to the intimacy of the other.

For me it's a human adventure. When we first contacted the agency, I asked them what kind of relationship we could hope for with whoever would give birth to our child. I could not imagine spending nine months without information about how she was doing and beyond that it's so generous what she does for us, I really wanted to have a friendly relationship with her. It was important, essential even, that we could get along with her. (...) The agency took note of it. I asked them about the attitude of same-sex couples taking this approach to the carrier and she told me that all homosexual couples actually wanted to have a close relationship with whoever would carry the child. Conversely, she told me that heterosexual couples almost refused to have contact with whoever carried the children. In that case it was more like "we make an order and we get the child back in the end" (Lucas, French, 35 y/o, partnership, no children).

In fact, the language used by these couples to describe the surrogate and the nature of her contribution to the parental project itself serves to create social bonds and intimate relationships between the various protagonists. For example, one of the surrogates is compared to an "aunt" or a "godmother" and this designation inscribes her into the child's kinship system. Another couple describes these new relationships as "extended family". Through what I call "bonding efforts in a logic of reciprocity", they elaborate an enlarged kinship universe. These couples see their children like interpersonal human beings, having close relationships with people other than the nuclear family, who are also part of their personal story.

We were there at the child's birth. We had a room at the clinic, next to Samantha's room, all together. Obviously we stayed with her after. (...) for 15 days after the birth, we regularly went to Samantha's place, we dined at their home with the baby, she bottle-fed him, she changed his diapers. We wanted to do this gently, without the brutality of saying, "Now it's OK, you completed your contract, bye". For us it was impossible to do something like that. And at the airport (...) it was a difficult moment because she cried, we cried, everyone cried since everyone loves each other. At that moment she said, "You are extended family". That's it, it became an extended family with them. (...) And we are in touch regularly. We talk on Facebook. Even today, six years after the first child was born, we chat. There is a bond and that bond will remain through my life. I know it, because it's so extraordinary what she did, that I cannot even imagine not answering her if she asks me a question or not being there if she needs us (Adrien, French, $48 \mathrm{y} / \mathrm{o}$, married, 6 y/o and 3 y/o children).

Other studies also mention exchanges by email, Skype and other forms of communication in order to maintain ties with the surrogate (see Gross, 2012, Smietana et al., 2014). Gay couples carry out a real relational work in order to 
create links with the surrogate and sometimes also with the egg donor, and thus guarantee their children access to their origins (see Dempsey, 2015 as cited by Gross, 2018). As I will describe below in more detail, French gay couples invest work and time in negotiating relationships with the third party through permanent social interactions, thus forming a relational network.

\section{Surrogate children's personhood: gay male couples' perspective}

We have, on the one hand, the configuration of corporeality and, on the other hand, the fabrication of personhood. Bodily components are mobilized to construct arguments that the child has the right to know her origins, because she is made of the biological and genetic contributions of others that are also part of her own personal genealogy and family narrative. The child is viewed as a social entity with a relational identity, whose best interest and well-being are taken into consideration.

The gay couple's relationship with the surrogate is nurtured both during and after pregnancy, outside the agency's regulated setting. Same-sex couples meet the surrogate and her husband, they exchange e-mails and photographs of pregnancy stages, they use Skype and Facebook to talk. They are present at the ultrasound scan to find out the sex of the child and also at their birth. There is a performative dimension, whereby the couple's constant involvement in the process (their joint endeavor), helps them as conceivers of a parental project to consider themselves future parents, and thus to perform the transition between intention and action.

In the beginning the relationship is artificially created by the agency, when there is a match between the couple and the surrogate. But after this inaugural moment, these couples voluntarily invest in maintaining this desired relationship, in order to create bonds, despite the contract's financial side. This introduces new relationships where free will and intention have a major place in the social construction of kinship.

Nevertheless, every party has their own distinct role appropriate to this new family configuration. Third parties are not parents and do not have the right to interfere with their children's education, because they do not belong to the domestic unit or nuclear family. Two factors make a gay family produced through surrogacy more similar to a traditional heterosexual nuclear family than other forms of homoparenthood: first, the possibility of forming a nuclear family consisting of only two legal parents with children biogenetically related to at least one of them; second, control over the reproductive process (Nebeling Petersen, 2016). At the same time, the absence of a mother makes such families very different to traditional heterosexual nuclear families in terms of gendered norms (ibidem). Gay couples have to manage the tension between old and new forms of family subjectivity and creation by doing "affective work" in contexts dominated by heteronormative social understandings (ibidem). This is because "a range of symbols and metaphors very conventional to heterosexual nuclear family formation are in play in this ostensibly unconventional context" (Dempsey, 2013, p. 51). Since "reproductive heterosex" remains the norm against which other modes of procreation are measured, gay couples who use offshore surrogacy experience 
"reproductive vulnerability" arising from their families being formed outside the norm (Riggs \& Due, 2013).

Despite lacking parental authority and responsibilities, the surrogate and her husband are considered part of the gay couple's family. This is a kind of "extended family" that has been forged and enlarged over time, based on regular contact and strong and lasting attachments. This continuous sharing includes both important life events (being invited to the couple's wedding) and occasional leisure activities (joint vacations or exchanging posts and comments on Facebook).

It will be our child, not hers. From the moment she agrees to donate, it is not her child. We have raised her, but I would be really happy, glad if [the surrogate] could share our life. Even from afar, in a friendly way, through photos from time to time (Lucas, French, 35 y/o, partnership, no children).

It is clear for us that we are the dads, we are the parents, but we want to create a bond for as long as possible. (...) And I think we were very lucky because she is an exceptional surrogate mother. (...) I think it was precisely when we met Patricia that the third party role was forged and materialized (Simon, French, $36 \mathrm{y} / \mathrm{o}$, married to Jean, $2 \mathrm{y} / \mathrm{o}$ twins).

We know that Patricia will have a role, a proper role in the story. There has never been any ambiguity about her role. She is not the mother, but at the same time she is not a stranger either. It's a special role, maybe a little bit like an aunt or a godmother. (...) She has already seen the children because she has been to France many times since they were born. She came to our wedding. (...) She has not interfered in our family life. It's more than a friend. She is part of the family, but not the nuclear family (Jean, French, 39 y/o, married to Simon, 2 y/o twins).

This trend is corroborated by other recent studies on the relationships gay couples have with women who carried and helped to give life to their children, where surrogacy sometimes creates a real "family innovation" — a "quasi-family" - and affinity is seen as a condition for success (Gross, 2018). In daily life, the child is raised by two fathers in a motherless scenario. However, the way couples envisage the story of this conception, and tell it to their children, does not exclude the representation of women who have contributed to their coming into the world as "mothers" with whom they want to retain links (ibidem). The language of "friendship" and "extended family"16 can help us understand the relationships between the prospective fathers, the surrogate-born children and the surrogates (Dempsey, 2015 as cited in Gross, 2018). Nevertheless, the closeness, nature and frequency of contacts depend on national contexts, i.e. on the socio-cultural proximity between the prospective parents and the surrogate (Courduriès, 2016), e.g. differences between surrogacy frameworks in the United States and in India.

16 This trend cannot just be explained by gay couples' effort to conform to the sexual alterity norm they also break through homosexual conjugality. In fact, long-term, large-scale studies on the relationships among gestational carriers point to similar relations (extended families and the like) for heterosexual users of surrogacy (see Jadva \& Imrie, 2014; Söderström-Anttila et al., 2015). In general, compared with families who use other forms of third-party reproduction, surrogacy families have been found to be more open about how their child was conceived. There is also continued contact between the surrogate's family and the intended family and their relationship remains close (ibidem). 
One of these couples had already spoken to the surrogate about the possibility of a second child (they had cryopreserved embryos) because they did not want to invest in the relationship with another surrogate with a different story. Another couple had already had two children with the same surrogate at her suggestion, because she did not want to start the process for another couple with whom she might have a worse relationship. As in Teman's study (2010), there seems to be a "sense of alliance" and personal commitment between the couple and the surrogate regarding the children already born or yet to be born.

In addition to the biological and genetic anchoring of kinship, a cultural and symbolic foundation is being constructed through the redefinition of the relationships between the prospective parents (including the male progenitor), the oocyte donor and the surrogate.

Regarding the egg donor, it's more complicated because she has the right to anonymity. However, we have the possibility of contacting her via a third party, the possibility of contacting her anonymously, and we will probably use this possibility to ask her later if she is ready to communicate with us, to give or receive some news and maybe answer the child's questions once she has them. (...) I think it's desirable to keep this relationship [with the surrogate] because we have lived this story with her, partly with her. It's more of a long-term relationship than with the oocyte donor because after all we haven't met her and she has donated at a given moment in time. After all, maybe for the child it will be more important to know her biological mother. I don't know (Théo, French, 35 y/o, civil union, no children).

Concerning the donor, it was just as important to us that she wasn't anonymous, but it's complicated and in the United States we didn't find donors who weren't anonymous. However, there is an arrangement where donors are anonymous, but when children turn 18 they have the opportunity to know who she is. (...) we wanted our children to know the truth of their story. And so it seemed acceptable to us to say that we didn't know the anonymous donor, but when they are adults, they have the possibility of doing it, they can see, know, get in touch with the donor, the biological parent, to get in touch with the surrogate mother and then have the whole picture. (...) the surrogate mother was considered to be a fundamental person in the children's story and we talked a lot about this, the relationship we had with the surrogate mother (Simon, French, 36 y/o, married to Jean, 2 y/o twins).

Despite the principle of the egg donors' anonymity that prevails in the United States, all the gay couples interviewed preferred semi-anonymity: they chose a donor who would remove anonymity after the child had reached the age of majority and expressed a desire to know her. She is thus sometimes called a "genetic mother" or "biological mother." The donor is always secondary, but the child's access to her own origins ("identity", "story") is prioritised. Prospective parents performatively invest in a network of possible long-term connections of relatedness and genealogy. Although there is not so much investment in personal relationships, some couples keep in touch with the egg donor by email, either directly or through an intermediary. The donor must always remain reachable throughout her life and must inform the couples of any change of address. 
We had two main conditions that weren't up for discussion. It's obviously that she is in good health, and second, we wanted her to agree to lift her anonymity. The donation is anonymous in the United States, but we wanted her to give her true identity. (...) I realized that many children who did not know their parents experienced pain, sometimes trauma, from not knowing their genetic background. And, since it is not actually a normal procedure nowadays, I really wanted to be sure to do my utmost for the well-being of my future child. (...) That if our child decides to contact her, that she agrees to get in touch with him or her, without necessarily developing a friendship, having a relationship, but that our child can meet her if she wishes, to know at least who her genetic mother is (Lucas, French, $35 \mathrm{y} / \mathrm{o}$, partnership, no children).

The donor is semi-anonymous because we want to be able to answer all our children's questions. If they ask "who gave the little seed?", we'll say "come on, we'll take a plane, we'll go to the United States, we'll see her". If he says "I don't want to see her", that's no problem, we won't see her. It's not an obligation. It's a tool. (...) We won't force him to meet the donor. He decides (Adrien, French, 48 y/o, married, 6 y/o and 3 y/o children).

Splitting motherhood into two dimensions (genetic and gestational) reduces the physical and biological role of each woman while recognizing both their contributions (Gross, 2018). It allows the gay couple (prospective parents) to strengthen their prominence in the accomplishment of the childbearing project (Courduriès, 2016). At the same time, the presence of whoever carried and gave birth to the child "allows the natural appearance of procreation to be preserved", in a hostile context where surrogacy is seen as "artificial and disembodied reproduction" (ibidem: 60). The difference between surrogates and oocyte donors is undoubtedly related to the way US agencies and clinics encourage contact with the carrier before and during the entire pregnancy while donors are usually selected through an online catalogue without personal contact (Dempsey, 2015, as cited by Gross, 2018; Murphy, 2015).

These couples attribute particular importance to genetic and medical factors in their choice of donor, i.e. factors related to physiognomy and age (health, success rates, ethnic match, etc.). Nevertheless, it seems to be a rejection of a market logic when gay couples seek to move away from the role of the consumer/customer who is able to choose reproductive services and exert control over biology and reproduction - by, for example, trying not to select the donor as if through a casting or mail-order catalogue.

The in vitro fertilization clinic has a database with egg donor candidates. With lots of information, photographs, physical information, a lot of health information as well as more personal information about who she is, what she does in life, why she is doing this, what she thinks about it, etc. So we have all this information and we choose according to that. The more important criteria were... very hard to say, but were health, age, since we were advised to pick someone relatively young. After that general assessment, we chose both based on their physical appearance and according to what they wrote in their descriptions (Théo, French, $35 \mathrm{y} / \mathrm{o}$, civil union, no children). 
It was more complicated for us regarding the donor. We realized we needed criteria. What are our criteria? So we chose very simple criteria. We said we want someone Caucasian, to avoid... Caucasian. We wanted her to have children already or for her to have already donated and it worked, because we didn't want failures. (...) We wanted local people. We didn't want something complicated and, most of all, we didn't want to do it by catalogue (Jean, French, 39 y/o, married to Simon, 2 y/o twins).

The incorporation of biomedical technologies and procedures, i.e. "embodied progress" (Franklin, 1997), raises novel sociocultural dilemmas. Technological innovation and scientific progress make possible new forms of choice, creating uncertainty and introducing relativism into kinship definition. Parenthood, kinship and procreation are culturally redefined (and even destabilized and denaturalized) within ART. "New reproductive technologies not only create new persons; they create new relations" (ibidem: 4). Thus, they have repercussions on the meanings of relatedness, and specifically on kinship understood in the traditional anthropological sense of ties established through procreation.

\section{Conclusions}

Third-party reproduction (gamete donation and gestational surrogacy) is a technologically-mediated way of bringing a child into the world and forging innovative family ties. It reveals the continuity of a naturalistic conception of kinship based on the valorization of a common biogenetic substance linking one of the prospective parents and the child. Biological processes such as pregnancy and delivery remain of great significance.

Although it is possible to standardize and regulate technical procedures (despite differences between national legislations that generate cross-border reproductive care and its subsequent criminalization), dilemmatic tensions persist because they are inherent to the process. How can couples call the child their own when she was created with the genetic material of a third party? Even if heterosexual couples and also lesbian couples - are engaged in a clear, voluntary process of anonymized gamete donation, the third party remains a threatening presence. Therefore, they develop arguments moving away from the concept of the third party as a real individual and focusing on the substance donated.

Conversely, the prevalence of a genealogical model of kinship leads gay couples to forge "family-like" ties with surrogates. They are concerned to avoid depriving the child of the story of her conception and birth, but they are also concerned to combat negative images and ethical controversies associating surrogacy with women's exploitation and body commodification.

The interviewees' conceptualization of third-party reproduction is based on the dichotomous opposition of gifts and commodities. The "contractual exchange" with third parties is either used by heterosexual couples to reduce the third-party role to a strict functionality (commodification) or, by contrast, it remains a spectre that gay couples try to ward off by forging human and emotional connections (collaboration). 
However, the differences among couples' attitudes towards the third party when using these reproductive techniques cut across different sexual orientations. In other words, these differences may be explained by the differences between using (solely) gamete donation and using gestational surrogacy, instead of those that exist between heterosexual and gay couples. ${ }^{17}$

Certain advances in biomedicine, such as ART, have made it possible to broaden the human experience; but they have also re-elaborated the line of demarcation drawn between living forms and human beings, while reconfiguring the contemporary conception of kinship and family.

\section{Bibliography}

Becker, G. (1997): Disrupted Lives - How People Create Meaning in a Chaotic World, Berkeley, University of California Press.

Berend, Z. (2014): "The social context for surrogates' motivations and satisfaction", Reproductive BioMedicine Online, 29, pp. 399-401.

doi: 10.1016/j.rbmo.2014.07.001

Cadoret, A. \& J. Wilgaux (2007): "Nécessaires anonymat et secret de soi. Réflexions sur les lois bioéthiques", Ethnologie française, 37, pp. 135-142.

doi: 10.3917/ethn.071.0135

Courduries, J. (2016): "Ce que fabrique la gestation pour autrui", Journal des anthropologues, 144-145, pp. 53-76.

doi: $10.4000 /$ jda. 6364

http://journals.openedition.org/jda/6364

Delaunay, C. (2015): "The beginning of life in the laboratory: The challenges of a technological future for human reproduction", Technology in Society, 40, pp. 14-24. doi: $10.1016 /$ j.techsoc.2014.09.001

Delaunay, C. (2017): "L'insupportable et l'incertain: proximité et dés-attachement dans l'assistance médicale à la procréation avec tiers donneur", Anthropologie \& Santé [Online], 15.

doi: 10.4000/anthropologiesante. 2738

http://journals.openedition.org/anthropologiesante/2738

Delaunay, C. \& A. Martins (2015), "Dialectical tensions between caregivers and patients in ART and Palliative Care: Ethical and moral issues raised by the (bio)medicalization of birth and death", in J. M. Resende \& A. C. Martins, ed., The Making of the Common in Social Relations, Newcastle upon Tyne, Cambridge Scholars Publishing, pp. 53-100.

Delaisi de Parseval, G. (2008): Famille à tout prix, Paris, Éditions du Seuil.

Dempsey, D. (2013): "Surrogacy, Gay Male Couples and the Significance of Biogenetic Paternity", New Genetics and Society, 32(1), pp. 37-53.

doi: 10.1080/14636778.2012.735859

Fine, A. \& A. Martial (2010): "Vers une naturalisation de la filiation?", Genèses, 78, pp. 121-134.

doi: $10.3917 /$ gen.078.0121

17 The present discussion might be transformed if the differences between heterosexual uses of IVF and AI, and heterosexual uses of surrogacy (genetic and/or gestational, commercial or altruistic) were also considered, especially because surrogacy is globally and for the most part a heterosexual practice. 
Fortier, C. (2009): “Quand la ressemblance fait la parenté”, in E. Porqueres i Gené, ed., Défis contemporains de la parenté, Paris, Éditions de l'EHESS, pp. 251-276.

Franklin, S. (1997): Embodied progress: a cultural account of assisted conception, London $\&$ New York, Routledge.

Gross, M. (2012): Qu'est-ce que l'homoparentalité, Paris, Payot.

Gross, M. (2018): "Pères gays et gestatrices: des liens "quasi-familiaux," in I. Côté, J. Courduriès \& K. Lavoie, ed., Perspectives internationales sur la gestation pour autrui. Expériences des personnes concernées et contextes d'action, Québec, Presses universitaires de Québec.

Harrington, J., G. Becker \& R. Nachtigall (2008): "Nonreproductive Technologies: Remediating Kin Structure with Donor Gametes", Science, Technology, \& Human Values, 33(3), pp. 393-418. doi: $10.1177 / 0162243907306695$

Jadva, V. \& S. Imrie (2014): "Children of surrogate mothers: Psychological well-being, family relationships and experiences of surrogacy", Human Reproduction, 29(1), pp. 90-96. doi: $10.1093 /$ humrep/det410

Lévi-Strauss, C. (2013): "Problèmes de société: excision et procréation assistée", in Nous sommes tous des cannibals, Paris, Seuil, pp. 81-101.

Martial, A. (2012): "La filiation, entre le social et le biologique", Les Cahiers français: Où va la famille?", 371, pp. 68-73.

Mathieu, S. (2013): L'enfant des possibles: Assistance médicale à la procréation, éthique, religion et filiation, Paris, Les Éditions de l'Atelier/Éditions Ouvrières.

Mauss, M. (1988): Ensaio sobre a dádiva, Lisboa, Edições 70.

Mehl, D. (2008): Enfants du don. Procréation médicalement assistée: parents et enfants témoignent, Paris, Éditions Robert Laffont.

Melhuus, M. (2012): Problems of Conception: Issues of Law, Biotechnology, Individuals and Kinship, New York, Berghahn.

Murphy, D. A. (2015): Gay Men Pursuing Parenthood through Surrogacy: Reconfiguring Kinship, Sidney, UNSW Press.

Nebeling Petersen, M. (2016): "Becoming Gay Fathers Through Transnational Commercial Surrogacy", Journal of Family Issues, pp. 1-27. doi: $10.1177 / 0192513 \times 16676859$

Riggs, D. W. \& C. Due (2013): "Representations of reproductive citizenship and vulnerability in media reports of offshore surrogacy", Citizenship Studies, 17(8), pp. 956-969. doi: 10.1080/13621025.2013.851145

Shanley, M. L. (2002): "Collaboration and Commodification in Assisted Procreation: Reflections on an Open Market and Anonymous Donation in Human Sperm and Eggs", Law \& Society Review, 36(2), pp. 257-284. doi: $10.2307 / 1512177$

Smietana, M. et al. (2014): "Family relationships in gay father families with young children in Belgium, Spain and the United Kingdom", in T. Freeman et al., ed., Relatedness in Assisted Reproduction: Families, Origins and Identities, Cambridge, Cambridge University Press, p. 192-211. 
Söderström-Anttila, V. et al. (2015): "Surrogacy: Outcomes for surrogate mothers, children and the resulting families-a systematic review", Human Reproduction Update, 22(2), pp. 260-276.

doi: 10.1093/humupd/dmv046

Teman, E. (2010): Birthing a mother. The surrogate body and the pregnant self, Berkeley and Los Angeles, University of California Press.

Théry, I. (2010): Des humains comme les autres: Bioéthique, anonymat et genre du don, Paris, Éditions de l'EHESS.

Théry, I \& A.-M. Leroyer (ed.) (dir.) (2014): Filiation, origines, parentalité. Le droit face aux nouvelles valeurs de responsabilité générationnelle (Report), France, Ministère des Affaires Sociales et de la Santé.

Thompson, C. (2005): Making parents: The ontological choreography of reproductive technologies, Massachusetts, The MIT Press.

Turner, V. (1969): The ritual process: structure and anti-structure, Ithaca, N.Y., Cornell University Press. 